\title{
Joint Infection
}

National Cancer Institute

\section{Source}

National Cancer Institute. Joint Infection. NCI Thesaurus. Code C78402.

An infectious process affecting a joint. Causative agents include bacteria, viruses, fungi, and parasites. 